\title{
Belgium: Prehistoric and Protohistoric Archaeology in the Intertidal and Subtidal Zones of the North Sea
}

\author{
Marnix Pieters, Tine Missiaen, Maikel De Clercq, \\ Ine Demerre, and Sven Van Haelst
}

\begin{abstract}
The evidence for submerged prehistoric remains and landscapes in the Belgian sector of the North Sea is scarce. The majority of finds dredged and trawled from the seafloor consists of palaeontological material, notably mammalian bone remains, dating from the Early and Late Pleistocene, and possibly the Holocene. Scarce palaeontological and archaeological finds come from the intertidal zone. The available data are rather limited and strikingly sparse compared to neighbouring countries, yet it is steadily growing since the SeArch project. Recent investigations of an area with exceptionally high concentrations of Late Pleistocene and Palaeogene bone finds in the 'Scheur' illustrates this development and offers a promising avenue for future research. Growing awareness among a broader public is similarly resulting in an increase in reported
\end{abstract}

\footnotetext{
M. Pieters $(\varangle) \cdot$ I. Demerre

Agentschap Onroerend Erfgoed, Brussels, Belgium e-mail: marnix.pieters@vlaanderen.be;

ine.demerre@vlaanderen.be

T. Missiaen $\cdot$ S. Van Haelst

Flanders Marine Institute (VLIZ), Ostend, Belgium

e-mail: tine.missiaen@vliz.be;

sven.vanhaelst@vliz.be

M. De Clercq

Renard Centre of Marine Geology, Ghent University, Ghent, Belgium

e-mail: Maikel.DeClercq@UGent.be
}

chance finds, mainly from beaches. In due course, these growing numbers will hopefully allow quantitative support for certain hypotheses.

\section{Keywords}

Palaeontological · Submerged · Protohistoric · Prehistoric $\cdot$ Palaeolandscape $\cdot$ Raversijde

\subsection{Introduction}

Compared to neighbouring countries, the general attitude in Belgium towards archaeological and palaeontological finds in the North Sea has long been marked by a genuine lack of scientific interest. The sparse archaeological research in the intertidal and subtidal zones of the Belgian part of the North Sea was often very fragmented and focused largely on wreck sites. With the recent SeArch project (Missiaen et al. 2017) and the new national law on underwater cultural heritage (see also later), this attitude has now changed completely. Together with better insights into submerged palaeolandscapes, this has resulted in an increasing awareness of the importance of (reporting) archaeological finds (see also Pieters et al. 2018 for a short overview).

So far, relatively few fossil bones have been reported from the subtidal zone (Fig. 9.1). This is 


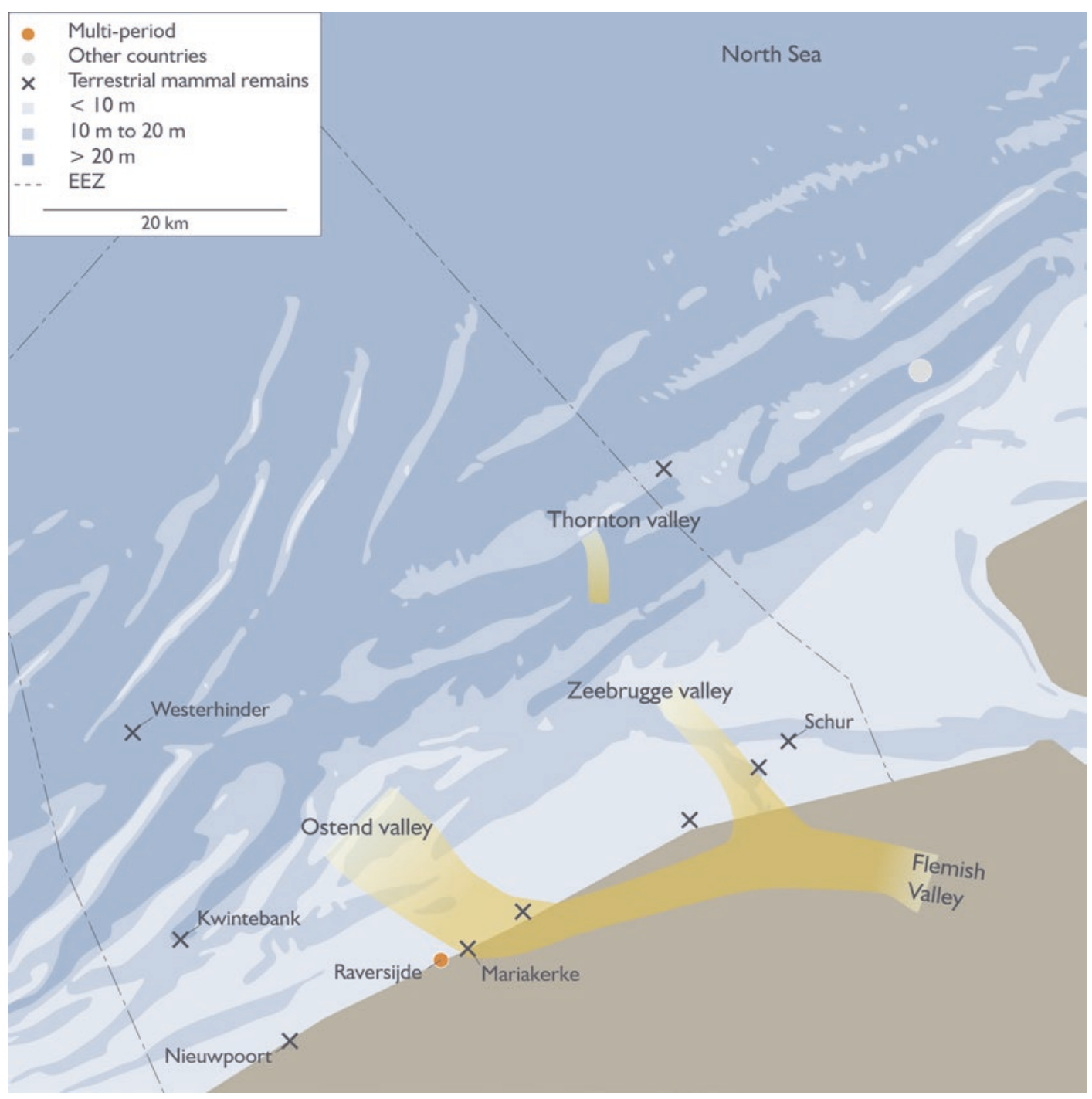

Fig. 9.1 Map with the locations of pre- and protohistoric archaeological evidence in the intertidal and subtidal zones of the Belgian part of the North Sea. Drawing by Moritz Mennenga

in stark contrast to the Netherlands where numerous tools and fossils have been reported (Van Kolfschoten and van Essen 2004; Mol et al. 2006; Hublin et al. 2009; Hijma et al. 2012; Peeters and Amkreutz, Chap. 8, this volume). The few mammal bone fragments that have been fished up largely date from the Last Glacial-Interglacial cycle (c. 120,000-12,000 years BP) (Demerre 2008; Vermeersch et al. 2015). Prehistoric artefacts have only been found in the intertidal zone. Since the late nineteenth century, numerous flint artefacts have been reported from beaches, probably because of the exposure of artefacts by erosion at the shore edge (Pieters et al. 2010). Archaeological investigation of the beach at Raversijde in the 1970s and 1980s resulted in numerous flints and a possible Bronze or Iron Age wooden paddle-like object (Pieters et al. 2010).

Roman artefacts recovered from the seafloor in the subtidal zone are quite scarce and mainly consist of ceramics. It is believed that most of 
these finds are related to Roman shipwrecks (Pieters et al. 2010). Artefacts from Medieval times mainly involve isolated finds from various locations. In contrast to the Roman finds, all the Medieval artefacts were found close to the coast $(<10 \mathrm{~km})$, which suggests a relation to coastal settlements and/or coastal navigation (Pieters et al. 2010).

Two prominent Roman period settlements are known from the intertidal zone (Wenduine and Raversijde). The latter has been the focus of a large-scale archaeological research project on land carried out by the Flanders Heritage Agency and the province of West Flanders (Pieters et al. 2006). Roman artefacts were often found in peat layers. Through time these peat layers were occasionally exposed (e.g., after major storms), but beach reconstruction during the past two decades in combination with the construction of groynes in the 1970s has resulted in the permanent burial of the peat layers under a thick (1-2 m) sand cover.

Five important Medieval settlements are known from the intertidal zone (Raversijde, Ostend, Bredene, Wenduine and Heist). Four of these have been identified as fishing settlements (the only exception being Ostend, which became a town). Beach finds in Ostend mainly involved potsherds, but other artefacts were also recovered from the harbour mouth (Pieters et al. 2010). In Raversijde the remains of a late Medieval fishing settlement were found (Pieters 1993, Pieters et al. 2013).

In this paper, we will focus on three specific finds from distinct time periods and different environmental settings:

- A wooden peel or paddle found in situ in a peat layer exposed in the intertidal zone in the 1960s and 1970s at Raversijde.

- Lithic artefacts and Iron Age pottery found as stray finds in the intertidal zone during 'fieldwalking' activities by archaeologists, local historians and amateur researchers in the late nineteenth and early twentieth centuries.

- Fossil remains of Pleistocene/Early Holocene terrestrial mammals found during fishing and dredging activities in the subtidal part of the North Sea but also accidentally found in the intertidal zone (on the beach at ebb tide) by casual passers-by.

\subsection{Archaeological Finds}

\subsubsection{Wooden Peel or Paddle}

This oak artefact (Fig. 9.2) was found in 1970 in situ on the beach of Raversijde (Fig. 9.1) in the so-called Subboreal 'surface peat', a welldescribed and well-known geological unit on the Belgian coastal plain (Baeteman 2007) that extends into the present-day North Sea. The growth of this peat layer has been dated by radiocarbon analysis in the area of the find spot between $4395 \pm 30 \mathrm{BP}$ and $2635 \pm 35 \mathrm{BP}$ (Deforce and Bastiaens 2013).

The artefact is $112 \mathrm{~cm}$ long, shows traces of wear and charring on the upper part of the blade and is perforated by boring organisms, probably the American piddock (Petricola pholadiformis) (Pieters et al. 2010, pp. 184-186). To provide for long-term conservation, it was impregnated with PEG (polyethylene glycol), and no attempt was ever made to obtain a radiocarbon date until 2015. The attempt in 2015 was successful in eliminating completely the contamination of the PEG, which is soluble in water (Van Strydonck and Van Bos 1998), and produced a date of $2573 \pm 29 \mathrm{BP}$, a result very close to the end of the peat growth at Raversijde. This result dates the object in cultural terms to the Bronze Age-Iron Age transition in the area of present-day Belgium. No function can be attributed with absolute certainty to this artefact. Its shovel-like shape suggests that it could be a baker's peel (used for removing bread from the oven) or a paddle. The most plausible interpretation would be a 'peel', but a combination of both cannot be excludedperhaps a peel recycled as a paddle.

The main conclusion from the analysis of this find must be to consider the surface peat in the coastal plain also as a potential archaeological unit, although this possibility has not so far been investigated further. Another possible argument to strengthen the archaeological context of the surface peat is the presence of numerous carbonized 
Fig. 9.2 Wooden paddle or peel found by Etienne Cools and Agnès Mortier in the Subboreal peat layer exposed on the beach of Raversijde. The peat was visible until the 1970s. Illustration by Marc Van Meenen and Hans Denis, Flanders Heritage Agency

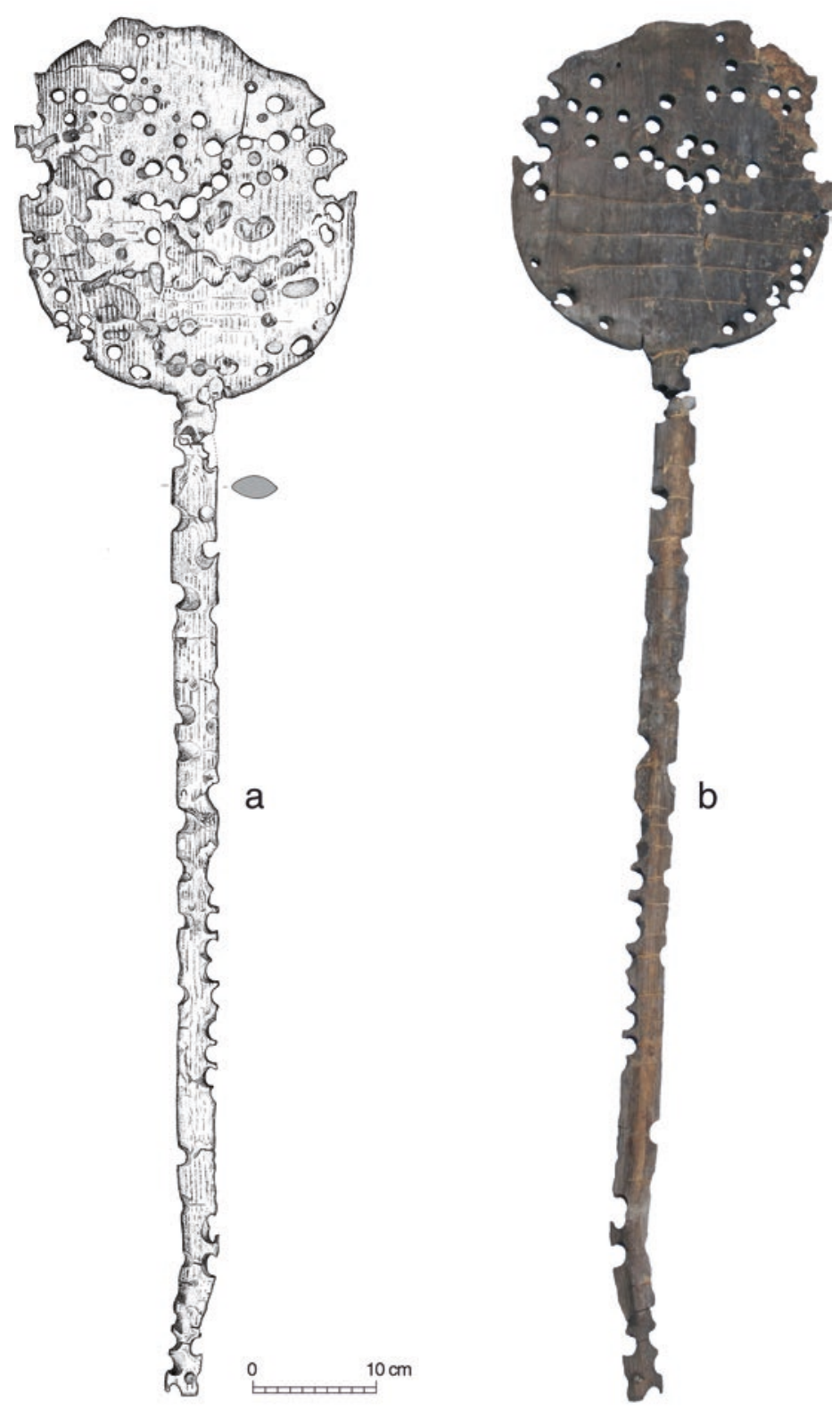

microscopic plant remains noticed during a pollen study in the same peat layer at Raversijde (Deforce and Bastiaens 2013). The presence of carbonized remains itself is not a guarantee of human activity in the area but deserves archaeological attention. This said, it should also be realized that this Subboreal peat layer was exploited intensively in Roman and Medieval times as a source of fuel (Pieters 2000) and as a consequence not much of it is preserved for future research.

\subsubsection{Lithic Artefacts and Iron Age Pottery Stray Finds}

The beach of Raversijde is well known among archaeologists for its intertidal Roman and Medieval archaeological structures and finds (Zeebroek et al. 2012). Less well-known is the fact that this beach also produced, according to Chocqueel (1950), some 262 flint artefacts of which nearly 100 have recently been re-examined 
by an expert in prehistoric lithic artefacts (De Bie 2013). Two so-called Tjongerian points (Fig. 9.3: $1-2)$ in the 'Chocqueel-assemblage' almost certainly date to the Late Upper Palaeolithic $(14,000-12,000 \mathrm{BP})$ and can be attributed to the Federmesser grouping. The other diagnostic tools in the available assemblage place a second occupation phase in the Neolithic (6500-5000 BP): the polished nature of the pieces and the large scraper suggest middle to late Neolithic (Fig. 9.3: 4-7).

These artefacts were all gathered in the first half of the twentieth century and no additional information is available as to their spatial distribution on the beach, their possible context or any related cultural features. In view of their age (late Palaeolithic and middle to late Neolithic) their reworking from foreshore deposits older than and underlying those surfacing at the beach in the first half of the twentieth century (Fig. 9.4) seems plausible.

Apart from this quantitatively and qualitatively important assemblage of prehistoric artefacts from Raversijde beach, a few flint artefacts were found in the late nineteenth and the first half of the twentieth centuries on almost every beach east of Nieuwpoort (Pieters et al. 2010). On the other hand, there are no records of such finds from the beaches to the west of Nieuwpoort. This remarkable distribution pattern seems at first glance related to processes of erosion and sedimentation: to the west of the river IJzer, the Belgian coast is building up gradually while to the east of the river IJzer the coast is gradually retreating (De Moor and Pissart 1992). This dynamic could explain the above-mentioned distribution pattern.

Neither the objects themselves from these other beaches nor any drawings or photographs of them are still available, which hampers a reinterpretation based only on the textual information. However, the fact that most beaches along the Belgian coast are known as find spots of at least a few flint artefacts emphasizes the archaeological value of the unusual assemblage of artefacts from Raversijde. When looking at the geology of the coastal zone, Raversijde is situated at the edge of a large buried palaeovalley (the so-called Ostend Valley), recently described in more detail (Mathys 2009; De Clercq et al. 2016). The presence of this Late Pleistocene buried palaeovalley makes the washing ashore of artefacts from underlying older deposits plausible.

Between the Stone Age and the Roman period, only a few sherds of Iron Age pottery have been found on the beaches of Bredene and Heist (Pieters et al. 2010).

\subsection{Palaeontological Terrestrial Mammal Remains}

In this section, we present an overview of locations with remains from fossil terrestrial and marine fauna that have been reported with certainty as coming from the intertidal or subtidal zone. This is largely based on intensive inventory work done by the Flanders Heritage Agency (Demerre 2008) and on an unpublished report from the SeArch project (Vermeersch et al. 2015). Eight find locations are reported: three from the intertidal zone and five from the subtidal.

\subsubsection{Intertidal Find Spots}

From the beach of Mariakerke (Ostend), there is a fossil tooth from a walrus (Odobenus rosmarus) probably of Weichselian age. The tooth belongs to the collection of the local museum De Plate in Ostend. The second intertidal find spot, the beach east of the harbour of Ostend, produced six bone finds, including fragments from a Weichselian mammoth and reindeer. On the beach at Blankenberge, a humerus fragment of a young aurochs was found (Fig. 9.5). Specialists such as A. Ervynck (Belgium) and M. PathouMathis (France) are convinced that this bone fragment belongs to a young aurochs and could be interpreted as a human artefact, as the humerus was broken at exactly the right spot to extract the marrow. Due to unclarified reasons, the radiocarbon analysis did not produce a reliable result despite two successive trials. Another bone frag- 

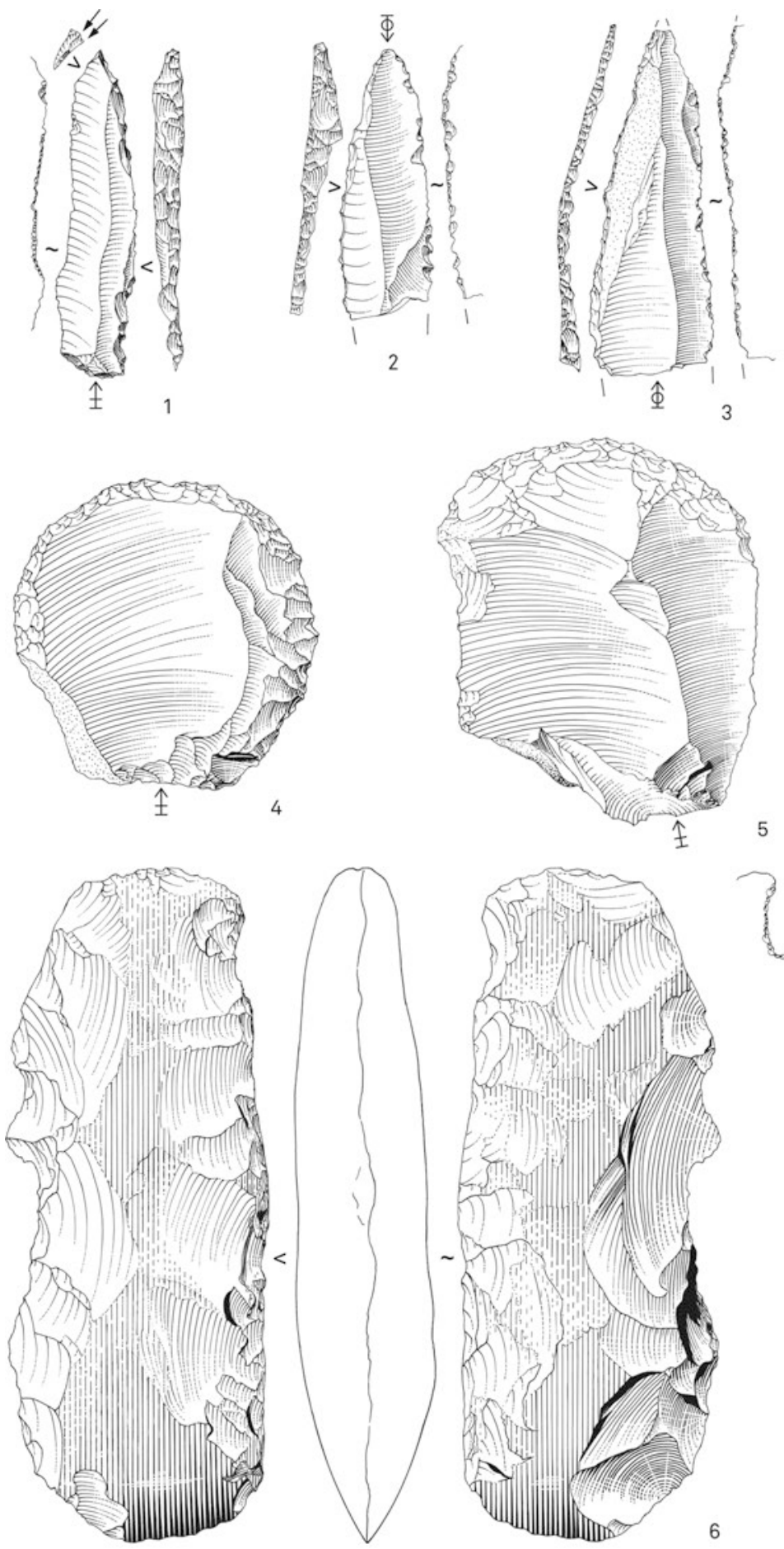

$5 \mathrm{~cm}$

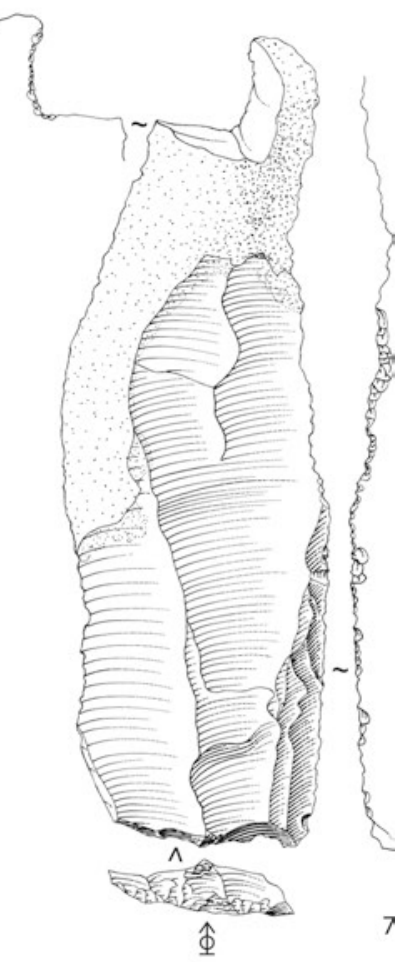

Fig. 9.3 Lithic artefacts found by A. Chocqueel at the beach of Raversijde. Illustration by Marc Van Meenen, Flanders Heritage Agency 


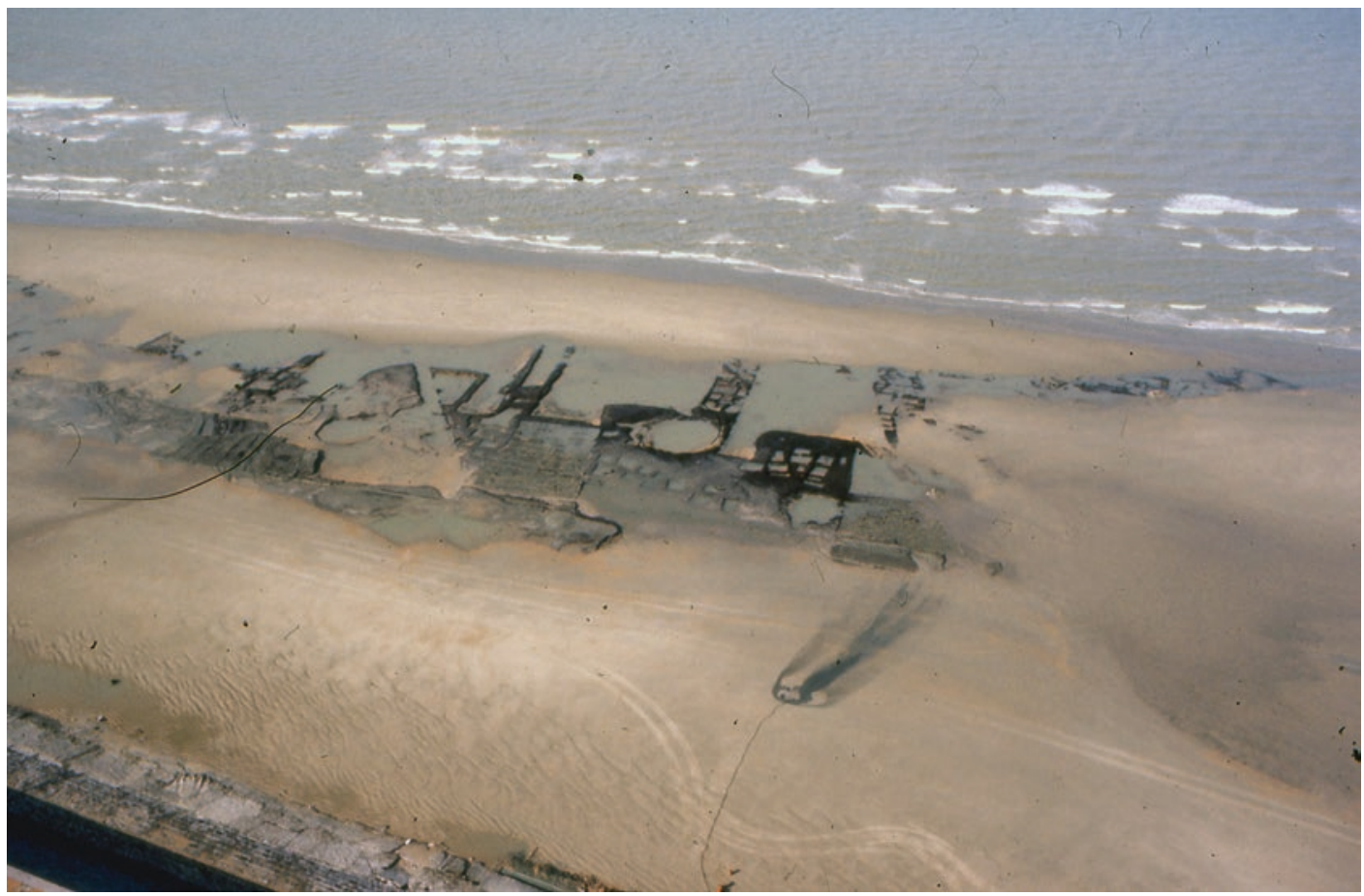

Fig. 9.4 Aerial picture of the beach of Raversijde in the early 1970s. The Subboreal peat eroding at the surface is clearly visible. Photo courtesy of Etienne Cools and Agnès Mortier

ment from an aurochs was uncovered in the harbour channel of Blankenberge, close to the above find, and has been submitted for radiocarbon dating.

\subsubsection{Offshore Find Spots}

A. Gautier in two papers on fossil walrus bones also mentions the find of a mammoth skull (Elephas primigenius or Mammuthus primigenius) of Late Pleistocene (Weichselian) age dredged from the North Sea near the Westhinder Bank. The skull was of particular interest because of its association with puparia of the subarctic blowfly (Protophormia terraenovae) (Gautier 1995; Gautier 1998). The skull itself is actually missing.

T. van Kolfschoten and H. Van Essen mention Early Pleistocene fossil remains from Tiglian deposits (2.45-1.8 million years) found close to the Thornton Bank. This sandbank extends from Belgian waters into the Dutch part of the North Sea, suggesting these finds may originate from the Dutch sector (Van Kolfschoten and Van Essen 2004) as no deposits of this age are found in the Belgian part of the North Sea (Mathys 2009). The authors mention Anancus arvernensis, Mammuthus meriodionalis, Eucladoceros sp. and Equus sp. D. Mol (1991) also mentions a molar from Anancus arvernensis found next to the Thornton Bank.

A sixth find spot is situated in the 'Scheur', a navigation channel towards the Westerscheldt northeast of the harbour of Zeebrugge, close to the so-called Zeebrugge wreck-site (Vandenberghe 1997). According to oral information by the people responsible for the salvage of this wreck, remains of a woolly rhinoceros (Coelodonta antiquitatis) were found in the immediate vicinity of the wreck. In this case also, the palaeontological remains themselves are missing. A small fraction of the fossil collection of the Ostend museum 'De Plate' consists of several palaeontological remains dredged from the 


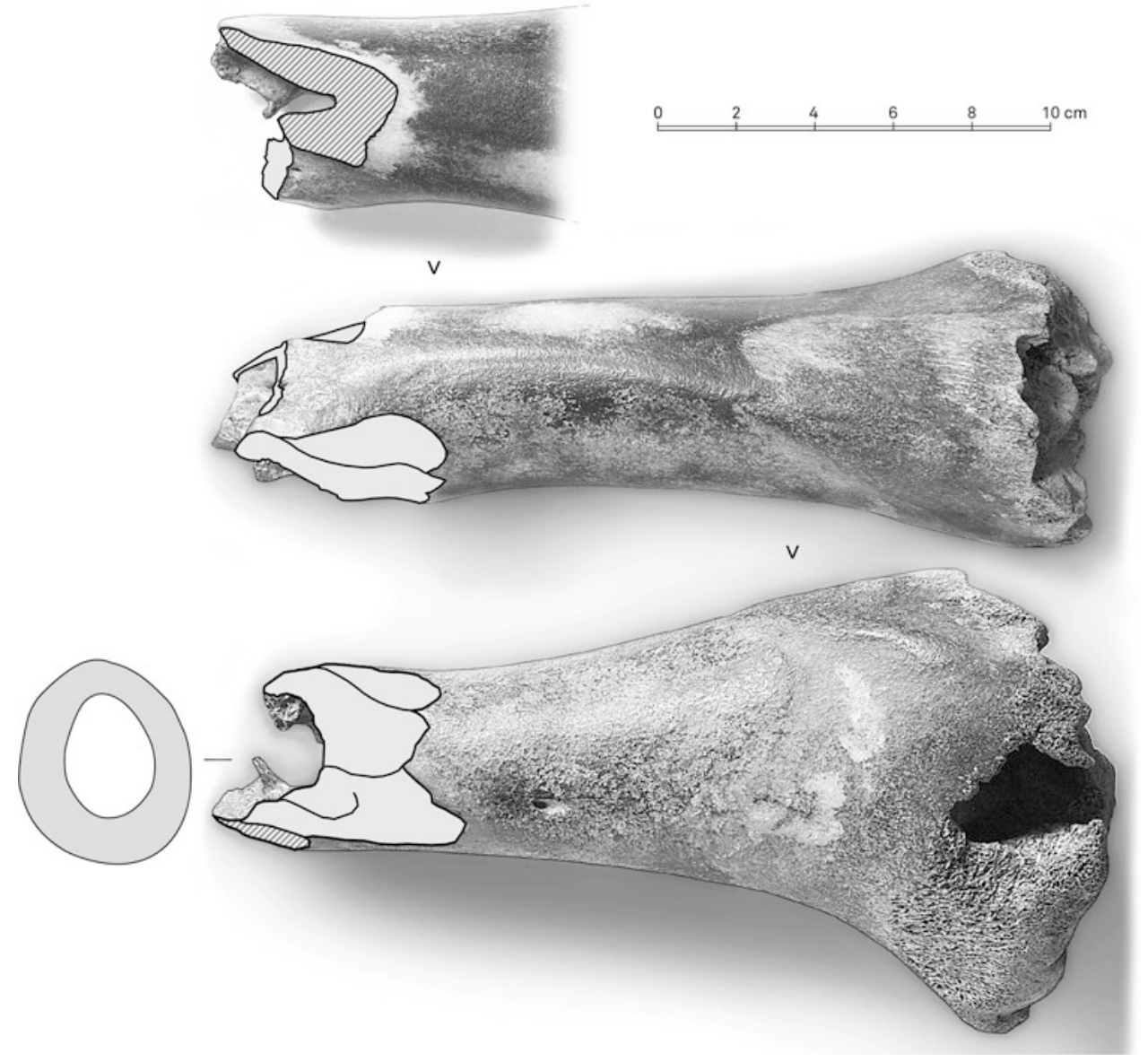

Fig. 9.5 Humerus fragment of a young aurochs. Illustration by Marc Van Meenen and Kris Vandevorst, Flanders Heritage Agency

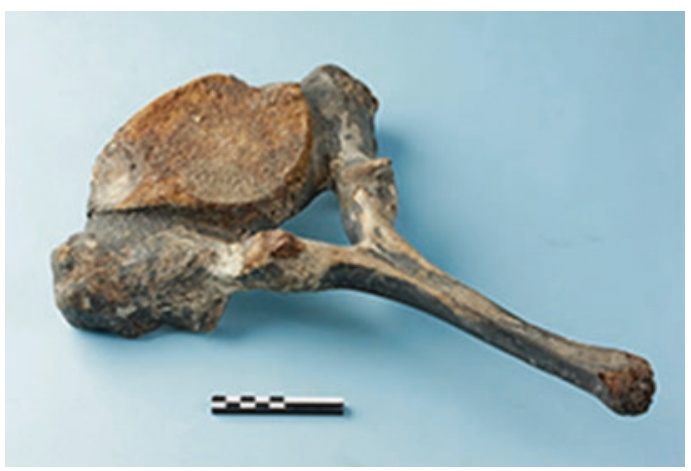

Fig.9.6 Thoracic vertebra from a mammoth (Mammuthus primigenius) or elephant (Elephas antiquus) found in the Zeebrugge harbour channel. Photo by Hans Denis, Flanders Heritage Agency navigation channel leading to the harbour of Zeebrugge. These finds consist of, among others, the thoracic vertebra of a mammoth (Mammuthus primigenius) or an elephant (Elephas antiquus) (Fig. 9.6). Whether these finds are connected with the find reported from the 'Scheur' is still under debate.

In 2008 a red deer antler was found during sand extraction activities on the Kwinte Bank. There are no tool marks on the antler and it seems to have been shed naturally (Wessex Archaeology 2008). It probably dates from the Early Holocene. Two palaeontological remains in the collection of the 'Aquarium of Ostend', but at present missing, are on a picture labelled as found respectively 
near the coast of Nieuwpoort and near the coast of Zeebrugge. Again, the latter find points to the same area as the navigation channels of the harbour of Zeebrugge and the 'Scheur'. The find from the coast of Nieuwpoort represents a separate locality.

With regard to age, the finds from the Thornton Bank area are early Pleistocene while the others are late Pleistocene (Eemian or Weichselian) or Early Holocene in age.

\subsubsection{The 'Scheur' Case Study}

Important new information has recently been obtained at the 'Scheur'. Due to maintenance dredging of the navigation channel, the upper, Holocene layers were removed, thereby exposing older Late Pleistocene and even underlying Palaeogene strata. Dutch fishing activities in the area have uncovered large quantities of palaeontological bone material over the past decades. This only recently came to the attention of Belgian scientists. As a result, two targeted surveys were carried out with RV Simon Stevin from the Flanders Marine Institute in July 2017. This produced more finds and made clear that remains from two fairly distinct geological periods are present in that location: the Pleistocenemainly remains of walrus (Odobenus rosmarus) but also including wild horse, aurochs and red deer-and the Eocene/Early Oligocene (rare whale remains, Archaeoceti) (Post et al. 2017). Based on the current finds, the site appears to be one of the largest and southernmost find locations of walrus bone material in the world (K. Post and D. Mol, personal communication, 2017). The bone material is most likely preserved in situ, derived from layers exposed on the seafloor. Determination and dating of the fossils are still ongoing at this moment. Further research (very-high resolution bathymetry and seismics, and shallow coring) will be done in the near future (2018) in order to gain a better understanding of chronology and palaeolandscape evolution.

\subsection{The Palaeolandscape Context}

If we compare the different find locations with a recent reconstruction of the base of the Quaternary sequence (Top-Palaeogene surface) (Mathys 2009, De Clercq et al. 2016), a correlation between geology and geomorphology (e.g., buried palaeovalleys) and palaeontological material seems plausible, although difficult to prove due to the limited precision of the find locations and the lack of geological context. The beaches of Mariakerke and east of Ostend, the Kwinte Bank and the Westhinder area are all situated in or near the Ostend Valley, whereas the find spot related to Zeebrugge (according to three different descriptions) is situated in the so-called Zeebrugge Valley. The beach of Blankenberge seems to be close to another buried palaeovalley, the so-called Coastal Valley, which is in fact the upstream section of the Ostend Valley (Mathys 2009; De Clercq et al. 2016; Heyse and Demoulin 2018). The find spot near the Thornton Bank may well be related to the buried Thornton Valley, and finally the find spot near Nieuwpoort can be associated with an ancient IJzer Valley. These data are of course not enough for a statistically valid analysis but the coincidence at this level is striking.

In a paper on Pleistocene faunal remains from terrestrial Belgium, Gautier (1985) distinguishes three types of palaeontological accumulations, and this provides additional useful information for understanding the subtidal and intertidal discoveries. One of Gautier's types is particularly relevant, namely faunal remains found as 'concentrations in the Flemish Valley'. The latter is a buried palaeovalley situated, broadly speaking, to the north of Ghent, which connects to the downstream Coastal-Ostend Valleys. The characteristics of these faunal remains found in concentrations, and their association with the presence of fly puparia, points to a specific taphonomic history that seems also to have been at play in the offshore Ostend Valley, notably the skull with puparia dredged up from the Westhinder Bank, slightly downstream of this valley. 
According to Gautier (1985) and Gautier and Schuman (1973), the presence of fly puparia (Protophormia terraenovae) in the skulls of large Pleistocene mammals, and their concentrated numbers, can be explained according to the following hypothetical sequence of events. Large mammals gathered in the lowland river valleys during winter, where some of them died due to the harsh conditions. In spring the frozen cadavers thawed and were washed downstream by peak spring meltwater discharge after the blowflies had already laid their eggs. Somewhere downstream the cadavers settled in certain areas favourable for burial and good preservation.

The link between the North Sea area and the onshore Flemish Valley makes it interesting to look at the setting of known Middle Palaeolithic archaeological sites on land in relation to the offshore topography (Crombé and Van Der Haegen 1994). Most of the known Middle Palaeolithic finds in Flanders come from the interfluves, but in the southern part of the Flemish Valley, more precisely in the area of Ghent, three sites have been located clearly within the valley infill itself. These sites were detected during development work and sand extraction between 75 and 40 years ago. Unfortunately, precise data are lacking on their lithostratigraphical context or their relationship to the palaeontological remains also reported from these locations. Consequently, no firm conclusions can be drawn on their geographical and geological setting, as they just reflect the locations of infrastructural works near the edges of the Flemish Valley. Nevertheless, the fact that Middle Palaeolithic sites are present in the Flemish Valley, regardless of whether they were in situ or reworked, provides insights into burial and preservation conditions that can plausibly be extended downstream to the CoastalOstend Valleys on the Belgian coastal plain. In particular, because of higher water tables, preservation conditions in valley infills are in general expected to be much better than for sites in other geomorphological settings.

The scarcity of reported bone finds from the Belgian part of the North Sea compared to the numerous finds reported from Dutch waters is absolutely striking (e.g. Louwe Kooijmans 1971).
This is probably partly due to the scientific neglect of these finds in Belgium, notwithstanding the fact that fishermen regularly reported their finds to museums during the second half of the twentieth century. Another reason could be the different geological setting whereby the Belgian sector is situated in an area dominated by erosion rather than sedimentation, as is the case in the Dutch sector of the North Sea (Hijma et al. 2012).

\subsection{Future Potential}

The specific finds discussed above cover all that is presently known about pre- and/or protohistorical archaeological and palaeontological finds in the Belgian part of the North Sea including the present-day adjoining beaches. The available data are, on the one hand, rather limited and notably scarce compared to neighbouring countries, but on the other hand they are steadily growing since the SeArch project. The recent investigations (summer of 2017) of an area with exceptionally high concentrations of Late Pleistocene and Palaeogene bone finds in the 'Scheur' is a good illustration of these developments and offers a promising avenue for future research. The growing awareness of the general public is similarly leading to an increase in reported chance finds, mainly from beaches on the modern shoreline. In due course these growing numbers will hopefully make it possible to test more effectively current hypotheses.

Underwater contexts, and wetland conditions more generally, offer better preservation conditions for organic materials, such as the wooden peel or paddle preserved in peat, and the blow fly puparia preserved in a mammoth skull, and this preservation potential will greatly extend the possibilities for new research compared to similar archaeological sites on land and above groundwater levels.

At present, new research in Belgium, focusing on the Pleistocene palaeolandscapes of the Belgian part of the North Sea and their archaeological/palaeontological potential, is in progress (De Clercq 2018). The results so far, which are 
visualized in a series of palaeogeographical maps, show that the preserved sediments are much more diverse than has previously been assumed (Mostaert et al. 1989; Mathys 2009). The sediments are best preserved in incised depressions and palaeovalleys cut into the TopPalaeogene surface. They originate from various depositional environments, ranging from fluvial to marine, and provide unprecedented information about the palaeogeographical evolution of the southern North Sea for the last 160,000 years. High-resolution sedimentary and seismic analysis provides detailed information about the depositional circumstances of these sedimentary bodies.

This PhD study will provide a geological context for the Pleistocene archaeology and palaeontology of the Belgian part of the North Sea (similar to Hijma et al. 2012), and will for the first time allow an assessment of the preservation potential of the various depositional environments (cf. Ward and Larcombe 2008). It clearly shows that integration of geophysical, geological/sedimentological and archaeological/palaeontological disciplines not only forms the key towards major breakthroughs in our knowledge on and understanding of the prehistory of Europe, but it also provides the best opportunity to develop tools, such as predictive maps of archaeological potential and risk, that can serve the needs of commercial-industrial end-users of the sea and the underwater archaeological heritage community.

For a long time, the strong divide between archaeology on land and archaeology at sea and the related misunderstandings about the difficulties of underwater research have had a negative impact on the possibilities for research on underwater cultural heritage, notwithstanding the huge potential. In Belgium this is finally changing, be it slowly. New ground-breaking interdisciplinary research is planned for 2018-2019 in the wider Zeebrugge region. The focus of this study, a collaboration between the Ministry of Public Works, Ghent University and Flanders Marine Institute, is to map the Quaternary palaeolandscape evolution and by linking this to the various fossil finds in the area to gain a better understanding of the archaeological potential of this highly dynamic area, including evidence of human occupation. The study will involve novel techniques such as OSL dating and sedaDNA, and the results will undoubtedly transform our understanding of Palaeolithic/Mesolithic archaeology in Belgium.

\subsection{Management of the Underwater Cultural Heritage}

Underwater cultural heritage as defined by UNESCO in the Belgian part of the North Sea is the responsibility of the Federal State of Belgium (Federal Governmental Service of Mobility and Transport). Since June 2014, Belgium has established a new active legislation related to underwater cultural heritage in the North Sea. That new legal framework has, among other things, defined a 'receiver of underwater cultural heritage', a new function similar to the receiver of wrecks in the United Kingdom but restricted to underwater cultural heritage. This new function is added onto the Federal portfolio of the governor of West Flanders (the only province in Belgium that borders the North Sea). Governors are civil servants of the Belgian regions (Flanders, Brussels Capital Region and Wallonia). The governor of West Flanders has two protocols of collaboration for the execution of tasks as receiver of underwater cultural heritage, one with the Flanders Marine Institute and the other with the Flanders Heritage Agency. The first deals with duties related to storage and conservation of finds, whereas the second is mainly concerned with scientific aspects related to these new heritage-related tasks.

Underwater cultural heritage as defined by UNESCO and present in the intertidal zone of the Belgian part of the North Sea is the regional responsibility of Flanders, taken care of by the Flanders Heritage Agency. The limit between the two zones of responsibility is the multi-annual mean low water at spring tide.

The Flanders Heritage Agency (Agentschap Onroerend Erfgoed) is a scientific institute of the Region of Flanders and has developed over the 
past two decades scientific and management skills and expertise in underwater cultural heritage including the intertidal zone. Together with the Flanders Marine Institute, the Flanders Heritage Agency also hosts an online database, $<w w w . m a r i t i m e-a r c h a e o l o g y . b e>$, on maritime archaeological heritage. Thanks to a new research mandate, the Flanders Marine Institute will be able in the near future to perform, coordinate and organize new and complementary research related to underwater cultural heritage, in close collaboration with academic institutions.

\section{References}

Baeteman C (2007) De laat holocene evolutie van de Belgische kustvlakte: Sedimentatie-processen versus zeespiegelschommelingen en Duinkerke transgressies. In: De Kraker AMJ, Borger GJ (eds) Veen-Vis-Zout. Landschappelijke dynamiek in de zuidwestelijke delta van de Lage Landen. Geoarchaeological and Bioarchaeological Studies 8:1-17

Chocqueel A (1950) Les civilisations préhistoriques \& anciennes de la Flandre Occidentale d'après l'examen d'objets leur ayant appartenu. Editions du Temple, Brussels

Crombé Ph, Van Der Haegen G (1994) Het MiddenPaleolithicum in Noordwestelijk België, Archeologisch Inventaris Vlaanderen. Buitengewone Reeks 3, Ghent

De Bie M (2013) Vuurstenen artefacten. In: Pieters M, Baeteman C, Bastiaens J, Bollen A, Clogg P, Cooremans B, De Bie M, De Buyser F, Decorte G, Deforce K, De Groote A, Demerre I, Demiddele H, Ervynck A, Gevaert G, Goddeeris T, Lentacker A, Schietecatte L, Vandenbruaene M, Van Neer W, Van Strydonck M, Verhaeghe F, Vince A, Watzeels $\mathrm{S}$, Zeebroek I (eds) Het archeologisch onderzoek in Raversijde (Oostende) in de periode 1992-2005. Vuurstenen artefacten, een Romeinse dijk, een 14deeeuws muntdepot, een 15de-eeuwse sector van een vissersnederzetting en sporen van een vroeg 17-deeeuwse en een vroeg 18de-eeuwse belegering van Oostende. Relicta Monografieën 8, Brussels, pp 67-72

De Clercq M (2018) Drowned landscapes of the Belgian continental shelf. Implications for northwest European landscape evolution and preservation potential for submerged heritage. $\mathrm{PhD}$ dissertation, Ghent University

De Clercq M, Chademenos V, Van Lancker V, Missiaen T (2016) High-resolution DEM for the Top-Palaeogene surface of the Belgian Continental Shelf. J Maps 12(5):1047-1054

De Moor G, Pissart A (1992) Het Reliëf. In: Denis J (ed) Geografie van België. Brussels, pp 130-215
Deforce K, Bastiaens J (2013) Het paleobotanisch onderzoek van het oppervlakteveen in profiel D. In: Pieters M, Baeteman C, Bastiaens J, Bollen A, Clogg P, Cooremans B, De Bie M, De Buyser F, Decorte G, Deforce K, De Groote A, Demerre I, Demiddele H, Ervynck A, Gevaert G, Goddeeris T, Lentacker A, Schietecatte L, Vandenbruaene M, Van Neer W, Van Strydonck M, Verhaeghe F, Vince A, Watzeels S, Zeebroek I (eds) Het archeologisch onderzoek in Raversijde (Oostende) in de periode 1992-2005. Vuurstenen artefacten, een Romeinse dijk, een 14deeeuws muntdepot, een 15de-eeuwse sector van een vissersnederzetting en sporen van een vroeg 17-deeeuwse en een vroeg 18de-eeuwse belegering van Oostende. Relicta Monografieën 8, Brussels, pp 52-55

Demerre I (2008) Maritiem archeologisch erfgoedonderzoek in 2006-2007. Twee jaar registratie en verwerking van het erfgoed in en uit de Noordzee. Vlaams Instituut voor het Onroerend Erfgoed, Brussels

Gautier A (1985) Pleistocene zoogdieren van België en waar ze gevonden worden. Lutra 28:121-123

Gautier A (1995) Bovenpleistocene zoogdieren van Oudenaarde Donk (België), fossiele vliegenpoppen uit de Vlaamse Valleien elders en nog een en ander over de Vlaamse Vallei. Cranium 12(2):73-81

Gautier A (1998) Fossiele walrussen (Odobenus rosmarus) aan de Belgische kust. Natuurwetenschappelijk Tijdschrift 78:122-127

Gautier A, Schuman H (1973) Puparia of the Subarctic Black Blowfly Protophormia Terraenovae (RobineauDesvoidy, 1830) in a skull of a Late Eemian (?) Bison at Zemst, Brabant (Belgium). Palaeogeogr Palaeoclimatol Palaeoecol 14:119-125

Heyse I, Demoulin A (2018) The Flemish valley: response of the Scheldt drainage system to climatic and GlacioEustatic oscillations. In: Dumoulin A (ed) Landscapes and landforms of Belgium and Luxembourg. Springer International, Cham, pp 297-311

Hijma MP, Cohen KM, Roebroeks W, Westerhoff WE, Busschers FS (2012) Pleistocene Rhine-Thames landscapes: geological background for hominin occupation of the southern North Sea region. J Quat Sci 27(1):17-39

Hublin J-J, Weston D, Gunz P, Richards M, Roebroeks W, Glimmerveen J, Anthonis L (2009) Out of the North Sea: the Zeeland ridges Neandertal. J Hum Evol 57:777-785

Louwe Kooijmans LP (1971) Mesolithic bone and antler implements from the North Sea and from the Netherlands. Berichten van de Rijksdienst voor het Oudheidkundig Bodemonderzoek 20-21:27-73

Mathys M (2009) The quaternary geological evolution of the Belgian Continental Shelf, Southern North Sea. Unpublished PhD thesis, Ghent University

Missiaen T, Pieters M, Maes F, Kruiver P, De Maeyer P, Seys J (2017) The search project: towards an assessment methodology and sustainable management policy for the archaeological heritage of the North Sea in Belgium. In: Bailey GN, Harff J, Sakellariou D (eds) 
Under the sea: archaeology and palaeolandscapes of the continental shelf. Springer, Cham, pp 415-424

Mol D (1991) Het ijstijdlandschap van de zuidelijke Noordzee. Grondboor en Hamer 45:9-13

Mol D, Post K, Reumer JWF, Van der Plicht J, De Vos J, Van Geel B, Van Reenen G, Pals JP, Glimmerveen J (2006) The Eurogeul-first report of the palaeontological, palynological and archaeological investigations of this part of the North Sea. Quat Int 142-143:178-185

Mostaert F, Auffret JP, De Batist M, Henriet J-P, Moons A, Sevens E, Van den Broeke I, Verschuren M (1989) Quaternary shelf deposits and drainage patterns off the French and Belgian coasts. In: Henriet J-P, De Moor G, De Batist M (eds) The quaternary and tertiary geology of the Southern Bight, North Sea. Belgian Geological Survey, Brussels, p 241

Pieters M (1993) Archeologisch onderzoek te Raversijde. Interim Verslag 1992. Archeologie in Vlaanderen II:247-264

Pieters M (2000) The impact of peat extractions on soil parent material in the area of the Medieval Village of Walravenside (Ostend, West-Flanders, Belgium). Pedologie-Themata 8:71-75

Pieters M, Demerre I, Zeebroek I (2006) Dijk uit de Romeinse tijd aangesneden onder het middeleeuwse vissersdorp Walraversijde. In: Bosman A, De Clercq W, Hoevenberg J (eds) Romeinendag, Jaarlijks Belgisch congres voor Romeinse archeologie. Universiteit Gent, pp 93-97

Pieters M, Demerre I, Lenaerts T, Zeebroek I, De Bie M, De Clercq W, Dickinson B, Monsieur P (2010) De Noordzee: een waardevol archief onder water. Meer dan 100 jaar onderzoek van strandvondsten en vondsten uit zee in België: een overzicht. Relicta 6:177-218

Pieters M, Baeteman C, Bastiaens J, Bollen A, Clogg P, Cooremans B, De Bie M, De Buyser F, Decorte G, Deforce K, De Groote A, Demerre I, Demiddele H; Ervynck A, Gevaert G, Goddeeris T, Lentacker A, Schietecatte L, Vandenbruaene M, Van Neer W, Van Strydonck M, Verhaeghe F, Vince A, Watzeels S, Zeebroek I (2013) Het archeologisch onderzoek in Raversijde (Oostende) in de periode 1992-2005. Vuurstenen artefacten, een Romeinse dijk, een 14deeeuws muntdepot, een 15 de-eeuwse sector van een vissersnederzetting en sporen van een vroeg 17-de- eeuwse en een vroeg 18de-eeuwse belegering van Oostende, Relicta Monografieën 8, Brussels

Pieters M, De Clercq W, Demerre I, Missiaen T, Van Haelst S (2018) Belgium - finds from trawl fishing, dredging and beach walking. In: Fischer A, Pedersen L (eds) Oceans of archaeology. Jutland Archaeological Society and Aarhus University Press, Aarhus

Post K, Hoekman A, De Wilde B (2017) Oerwalvissen op de bodem van de Noordzee. Cranium 34(1):48

Van Kolfschoten T, Van Essen H (2004) Palaeozoological heritage from the bottom of the North Sea. In: Flemming NC (ed) Submarine prehistoric archaeology of the North Sea, Research priorities and collaboration with industry CBA Research Report, vol 141. Council for British Archaeology, York, pp 70-80

Van Strydonck M, Van Bos M (1998) 14C-datering van met PEG behandeld nat opgegraven hout. Lunula Archaeologica Protohistorica VI:83-87

Vandenberghe S (1997) Découvertes importantes de la fin du 15 ème et le début du 16ème siècle provenant du fond de la mer du Nord en face du port de Zeebrugge. In: De Boe G, Verhaeghe F (eds) Travel technology $\&$ organisation in Medieval Europe, Papers of the 'Medieval Europe Brugge 1997' Conference, vol 8. IAP-Rapporten 8, pp 87-90

Vermeersch J, Demerre I, Pieters M, Van Haelst S, De Hauwere N (2015) Paleontologische resten afkomstig uit het Belgische deel van de Noordzee of aangetroffen op de aanpalende stranden. Unpublished report SeArch-project WP 1.5.1A

Ward I, Larcombe P (2008) Determining the preservation rating of submerged archaeology in the post-glacial southern North Sea: a first-order geomorphological approach. Environ Archaeol 13:59-83

Wessex Archaeology (2008) Hanson_0171_a: Two sherds of Roman Samian ware and a piece of antler. Unpublished report

Zeebroek I, Demerre I, Deckers P (2012) The site of Raversijde beach. A test site for geophysical research techniques. In: Fenwick V, Poudret-Barré A, Momber G, Demerre I, Zeebroek I, Bowens A, Chatelin C (eds) Archaeological Atlas of the 2 Seas. A crossborder maritime archaeology project, Final report 2009-2012. Hampshire and Wight Trust for Maritime Archaeology, Southampton, pp 32-35

Open Access This chapter is licensed under the terms of the Creative Commons Attribution 4.0 International License (http://creativecommons.org/licenses/by/4.0/), which permits use, sharing, adaptation, distribution and reproduction in any medium or format, as long as you give appropriate credit to the original author(s) and the source, provide a link to the Creative Commons licence and indicate if changes were made.

The images or other third party material in this chapter are included in the chapter's Creative Commons licence, unless indicated otherwise in a credit line to the material. If material is not included in the chapter's Creative Commons licence and your intended use is not permitted by statutory regulation or exceeds the permitted use, you will need to obtain permission directly from the copyright holder.

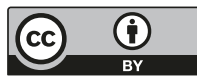

